International Research Journal of Management, IT \& Social Sciences
Available online at https://sloap.org/journals/index.php/irjmis/
Vol. 5 No. 6, November 2018, pages: 26 39
ISSN: 2395-7492
https://doi.org/10.21744/irjmis.v5n6.334

\title{
Influence of Implementation on Mix Promotion Model Strategy towards Tourist Visitation in Indonesia
}

Janri D. Manafe ${ }^{a}$

Tuti Setyorini $^{\text {b }}$

Yermias A. Kay Alang ${ }^{c}$

Article history:

Received: 5 July 2018

Accepted: 30 September 2018

Published: 19 October 2018

\section{Keywords:}

Marketing;

Mix promotion;

Promotion strategies;

Rote island;

Tourists visitation;

\begin{abstract}
This quantitative study aims at examining how the implementation of promotional mix model strategy, that consisted of nature tourism, arts, and culture, influencing the increase of both domestic and international tourists visitation in Indonesia. The study was conducted in Rote as a tourism Island that located in East Nusa Tenggara- Indonesia. Data itself obtained through questionnaires. Results shows that independent variables consisting of advertising, sales promotion and personal selling, have shown a significant influence and have given positive impact on tourist visitation to Rote Island. In other side, variables of public relations and direct marketing have no effect on tourist visitation to the Rote Island.
\end{abstract}

2395-7492@ Copyright 2018. The Author. This is an open-access article under the CC BY-SA license (https://creativecommons.org/licenses/by-sa/4.0/) All rights reserved.

\author{
Author correspondence: \\ Janri D. Manafe, \\ Business Administration Departement, Kupang State Polytechnic \\ East Nusa Tenggara, Indonesia \\ Email address: janrimanafe@yahoo.co.id
}

\section{Introduction}

Current tourism trend has changed in tourists consumers-behavior pattern. Tourists do not only focus on relaxing and enjoying the sun-sea and sand (Munarsi, 2005). Current consumption pattern has begun to change to a higher type of tourism that is, enjoying the cultural product of a region or country. One of the areas in Indonesia which has a variety of tourist attractions is Rote Island.

Rote Island is famous for its tourism potential which is quite diverse. Many attractions are presented in this area. Some of them are potential of nature, art, and culture that can be an attraction for both foreign and domestic tourists. Rote Island is a small Island located in the province of East Nusa Tenggara, Indonesia. It is the Southern Island in Indonesia that is very close to Australia. The Island is also called Roti Island. There are many tourist attractions that

${ }^{a}$ Business Administration Departement, Kupang State Polytechnic, Indonesia

${ }^{\mathrm{b}}$ Business Administration Departement, Kupang State Polytechnic, Indonesia

${ }^{\mathrm{c}}$ Business Administration Departement, Kupang State Polytechnic, Indonesia 
can be visited in Rote. There are also a lot of interesting natural tourism objects, for example, Nembrala Beach. As a surfing place that has a very good sea wave, Nembrala Beach has been one of international surfing competition beach.

Rote Island is rich in arts. Its traditional dance is diverse and amazing. The Island tradition that utilizes lontar leaves to be a traditional cap (called Ti'i Langga), as well as to be a traditional music (called Sasando), and to be another woven thing has drawn its Island becoming a more unique Island. Lontar trees can also produce sugar plate (brown sugar) and liquid sugar (brown liquid sugar). Besides that, woven belt with a variety of shades in Rote Island has become an icon of Rote Island. Counting those thoughts, that Rote Island has got so many potential tourists to attract, we state that it is necessary and needed to be responded with the appropriate tourism marketing model. The appropriate model will bring a lot of benefits into tourism objects itself, and into Rote Island people in particular.

The strategy, which has been conducted by Department of culture and tourism of Rote Ndao Regency, is too simple, therefore, the strategy itself is not able to increase the number of domestic and international tourists visitation. As a result, it affects on receipt of the PAD in the tourism sector. In accordance to what has been stated above, we have conducted this study with an assumption that; to increase the number of visitation of both domestic and international tourists to Rote Island, Mix Promotion strategy (Kotler, 1964; 1993) is suitable as a Tourism Marketing Model. The strategy of Mix Promotion has 5 (five) sectors, namely: advertising, sales promotion, public relations, personal selling, and direct marketing. Based on the above description, we conducted a research on examining how the implementation of promotional mix model strategy, that is nature tourism, arts, and culture, has influenced the visitation increase of both domestic and international tourists to Rote Island, Indonesia.

\section{Materials and Methods}

We, in this section, present related theory, a brief explanation of Rote Island, and technique of collecting the data as well as the technique of analyzing the data.

\subsection{Tourism Marketing}

Marketing is a strategic process that aims at harmonizing the sources in the same purpose as an opportunity that exists in the market (Swastha, 1984). Marketing tourism, according to Holloway (1995), consists of 7 P, i.e. positioning, product, price, place, promotion, packaging, and partnership. According to Lumsdon (1997), marketing of tourism are: "Marketing in tourism to be understood as the systematic and coordinated execution of business policy by tourist undertaking whether private or state-owned at the local, regional, national and international levels to achieve the optimal rate of satisfaction of the needs of identifiable consumers group and in doing so to achieve an appropriate return ". In other words, tourism marketing is a system of coordination that is applied by a company for the tourism industry (Swastha \& Irawan, 2005). The purpose of the system is to achieve the satisfaction of tourist or travelers by having a reasonable profit.

Based on the definition above, it can be inferred that the sense of tourism marketing is a societal process, in which individuals and groups obtain what they need in a system of planned business activities. The activities are designing a plan, determining price, promoting and distributing goods, as well as managing the service itself (Tjiptono, 2008). It also manages the relationship of customers in a well profitable way in order to produce goods and services (Yasid, 1999).

\subsection{Promotion Strategy}

Sistaningrum (2002) states that promotion is companies' effort or activity in order to affect actual consumers or potential consumers, so they will be persuaded to make a purchase of a product offered, both in current time and in the future. To be effective in promoting, promotional mix, that is an optimal combination of different activities, is needed. It is done to optimize promotion and to select the most effective method in increasing sales.

There are four types of promotional activities (Kotler, 1993), such as 1) Advertising, that is, a form the nonpersonal promotion using a variety of media in order to stimulate purchases (Shim, 2003). 2) Personal Selling, that is, a personal promotion form by oral presentations in a conversation with a prospective buyer. It is conducted to stimulate purchases. 3) Publicity, that is a form of nonpersonal promotion regarding services of certain business by reviewing data/ information/ news about it. In general, this type is a scientific form. 4) Sales promotion, that is, a form of promotion

Manafe, J., Setyorini, T., \& Alang, Y. (2018). Influence of implementation on mix promotion model strategy towards tourist visitation in Indonesia. International Research Journal of Management, IT and Social Sciences, 5(6), 26-39. 
that has not included in those three mentioned above. However, it has the same purpose that is to stimulate purchases. 5. Direct marketing, that is, a form of direct individual sales aimed at influencing consumer purchase (Sutisna, 2003).

Theory applied in this research is push strategy and pull strategy theory. Push strategy is the promotional activities conducted on intermediaries. The purpose of the intermediary is to promoting its products towards last consumers. Usually, this strategy applied personal selling (face-to-face sales) and sales promotion. Face to face sales media consists of sales presentations, sales meeting, samples, and exhibition. While the sales promotions applied approaches using contests, games, giveaways, sweepstakes, lottery, exhibitions etc. The pull strategy is a promotional activity that conducted directly to the last consumer. This strategy has usually applied direct marketing advertising and public relations (Oliver, 2007).

Advertising use media advertisements in the mass media both print and electronic advertising as well as outside space in the form of billboards, posters, banners, brochures, display materials, film/VCD, etc. Direct marketing is in form of catalogs, letters, e-mails, tv shopping etc. Public relations is in the form of press kits, company magazine, publication, sponsorship, etc. The use of a promotional strategy can be seen through the large number of promotions uses, promotional media and budgets that used in promotional activities.

\subsection{Marketing Mix}

After determining the target market as well as the position of the desired by consumers, companies need to design the program so that the product can obtain a response from the target market. Marketing requires a tool that is a program that can be controlled by the company. Marketing strategy is also called marketing mix. According to Buchari (2007), there are four components that are included in the activity of marketing mix. It is famous as 4 Ps. They are Product, Price, Place, and Promotion. Marketing mix, according to Kotler and Keller (2007), is a marketing tool that used the company to pursue its business purpose. Thus, it can be concluded that the marketing mix is a device consisting of a product, price, promotion, and distribution, which will determine the level of marketing success. It is aimed at getting the desired response of the target market.

\subsection{Tourist Attraction}

An aspect that has great determination in the development of the tourism industry is tourism and tourist attractions. Tourism product and tourist attraction are two different things. Yoeti (1996) explains that terminology of tourism product, or object of tourism, is not known in the overseas. There is the only terminology of tourist attraction while in Indonesia, both terminologies are known as a different meaning.

Each them stands for their own understanding. The object of tourism is very interesting thing that can be seen and be felt by tourists, that comes from nature. While tourist attractions are something interesting to be seen, felt, enjoyed and owned by tourists, that made by humans. It requires advance preparation before being shown to tourists. More understanding of tourism objects can be seen from some following references.

1) Government Regulation No. 24/1979 explained that the tourism object is the embodiment of human creation, life, art, and culture as well as the history of the peoples and places or nature state that has an attraction to be visited.

2) Decree of Tourism Ministry No.: KM. 98/PW. 102/MPPT-87 explained that tourism object is a place or nature state that contains tourism resources, or has been built and developed to be a visited place by tourists.

Based on the description above, it can be concluded that tourism object and tourist attractions are the same. However, Yoeti (1996) in his book entitled 'Introduction to Tourism Science' explains that the tourism object and tourist attractions are totally different. Next, to be a good tourist destination, a place or an area should be developed. There are three (3) things need to be developed in order to make the area interesting. They are:

1) The existence of 'something to see'. 'Something to see' means something interesting to be looked or watched by tourists.

2) The existence of 'something to buy'. 'Something to buy' means there must be a typical thing that can be purchased by visitors. 
3) The existence of 'something to do'. 'Something to do' means there is an interesting activity that can be done or conducted on the place.

Those three elements that have been explained above are strongly needed for creating a tourism destination. For the development of a tourist destination, there must be something to be considered. Things must be considered namely: 1) must be able to compete with other existing attractions or other similar attractions; 2) must be stable, unchanged, and does not move, unless for reconstruction and development matter; 3) must have adequate facilities as well as infrastructure. Furthermore, it must have its own distinctive characteristics that are usually called as tourism icon; and 4) should be interesting, while the local community must aware of tourism.

\subsection{Rote Island}

Rote Islands also called the Island of Roti, is an Island in East Nusa Tenggara Province, Indonesia. East Nusa Tenggara Province itself is located between 80-120 South latitude and 1180-1250 East longitude, with a land area of $47,349.9 \mathrm{~km}^{2}$ and has a total area of a sea of $200,000 \mathrm{~km}^{2}$. The number of Islands in East Nusa Tenggara province is 566 Islands. 42 Islands have been inhabited while the uninhabited Islands are 524. NTT has got 21 regencies. One of the island, as well as the Regency, is Rote.

Similar to another place in Indonesia, East Nusa Tenggara have 2 seasons. They are dry season and rainy season. In June-September wind flows from Australia. The wind does not contain enough vapor. Therefore it creates a dry season. In December - March there is wind with enough vapor that comes from Asia and the Pacific Ocean. It creates a rainy season.

Rote regency is the southernmost region of Indonesia. The Island is famous for its cultivation of lontar, natural beach tourism, sasando traditional music, and traditional hat called Ti'i Langga. Through Act No. 9 the year 2002, Rote has become a regency in East Nusa Tenggara Province with a legal name as Rote Ndao Regency. Rote has 96 Islands. 6 of them have been inhabited. The region is an arid climate that is influenced by the monsoon winds. It has an only a short rainy season (3-4 months). The North and South of Rote are mainly beaches and lowlands while the central part of it is valleys and hills. This Island can be surrounded in a short period of time. Following is the map of East Nusa Tenggara Map with a red mark of Rote Island.



Figure 1. Map of East Nusa Tenggara Province, Indonesia

Source: Google Map

Manafe, J., Setyorini, T., \& Alang, Y. (2018). Influence of implementation on mix promotion model strategy towards tourist visitation in Indonesia. International Research Journal of Management, IT and Social Sciences, 5(6), 26-39. https://doi.org/10.21744/irjmis.v5n6.334 


\subsection{Research Method}

This study examines the influence of implementation on the Mix Promotion strategy towards tourists visitation in Rote Island. This is a kind of verification study since this study aims at examining the influence of marketing mix implementation, as service competition in gaining an advantage, towards the decision process of tourists visitation in Rote Island. This type of inquiry is a type of causality while the time coverage is cross-sectional. The unit of analysis is the tourists/ travelers (customers). The technique used is sample withdrawal that applied purposive sampling. The samples were 100 tourists who visited tourism object in the Island of Rote. This study used 2 types of data, namely primary and secondary data. The data analysis used multiple regression analysis. Research variables used in this research and the operational variable definition in this research are 1) Independent variable, namely: Advertising ( $X$ 1), Sales promotion, Public Relations (X 3), Personal Selling (X 4), Direct Marketing (X 5). 2) The dependent variable, namely: Visitation decision of domestic tourists and International tourist on Rote Island - East Nusa Tenggara (Y).

In order to make this research clearer, the operational variables need to be defined in advance. The operational definition is a definition given in a variable by adding meaning or specifying activities or justify an operation that is needed to measure these variables. Definition of operation of this research is defined into a number of indicators including:

1) Independent Variable; Independent variables are the variables that impacted bound variables, both positively and negatively.

\section{a) Advertising}

Advertising is a non-personal form of communication that purchased through mass media such as newspapers, magazines, radio, television, travel guides, billboards and so on. Advertising is used to achieve a variety of goals, included consumer behavior, constructing an image, and achieving the desired sales.

\section{b) Sales promotion}

Sales promotion involves all activities that offer incentives to influence potential consumer desires, intermediating product, or achieving sales targets. Sales promotion will add more value to all product. For example, free accommodation is often used in product sales promotion of hotels and restaurants who want to increase demand within a certain period. However, generally, the incentives offered is in a limited time only. Sales promotions are often used and combined with other promotion tools in order to support the overall marketing efforts.

\section{c) Public relations}

It is a non-personal communication that is intended to change opinion, or at least, to reach coverage audience as large as possible.

\section{d) Personal Sales}

It is a direct communication or a face-to-face communication between tourism agent and tourists. It is conducted to giving more information or understanding about tourism object or tourism attractions to the tourists. The information is offered to the tourist so the tourists will be interested to visit tourism objects or tourism attractions.

\section{e) Direct marketing}

Direct marketing is a marketing approach that is opened to use any distribution channels, and/ or marketing communication, that is, allows marketers to have its own strategy in approaching consumers.

2) The Dependent Variable: The Increased Visitation of Domestic and International Tourists to Rote Island -East Nusa Tenggara (Y).

Next, the following is the explanation about population and sample in this research. According to Sugiyono (2007), the population is the generalization of the object/subject that has certain characteristics and specific quantity to be studied by researchers (Pattiasina et al., 2018). In this study, the population is infinitive, or, in other words, the population cannot be determined or measured. The population is the domestic tourist and international tourists who were visitation Rote Island in a periodic time. Sugiyono (2007) also proposed a meaning of sample. He stated sample as a portion of numbers and characteristics that owned by population. Due to the infinitive population, in gaining samples, we applied the accidental sampling technique. The research has taken about 3 months to get 100 respondents in the Rote Island. 
The type of data in the research is primary data. Primary data has been retrieved from the data source, that is, from the individual respondents, such as from an interview or questionnaires (Husein, 2005). The data source used in this study was obtained by the respondent's responses to a questionnaire about advertising, Sales promotion, Public Relations, Personal Selling, Direct Marketing and tourist visitation to Rote Island.

In another hand, we used questionnaires to collect data. Questionnaires are the methods used to collect data by giving a list of closed and open questions about research object (the respondents) and asked them to answer questions or fill the questionnaires. The list of questions was drawn up on indicators. Next, after questionnaires were answered by respondents, the questionnaires were collected, selected, processed, and then analyzed.

Finally, after data needed has been collected, we analyzed it. There are two kinds of data, qualitative and quantitative data. The analysis of qualitative data is a form of analysis that based on the data expressed in words descriptions (Sutopo, 2002). Qualitative data itself is data that can only be measured directly (Hadi, 2001). To obtain quantitative data, the researchers used Likert scales. It was gained from the list of questions which are classified into five levels (Sugiyono, 2005), namely:

1) For the answer of "SD" Strongly Disagree, the score given is $=1$

2) For the answer of "D" Disagree, the score given is $=2$

3) For the answer of "N" Neutral, the score given is $=3$

4) For the answer of "A" Agree, the score given is $=4$

5) For the answer of "SA" Strongly agree, the score given is $=5$

Stages of quantitative data analysis used in this study are as follows: First, a test of Data Quality; Second, a test of Classic Assumption; and third, Multiple Linear Regression Analysis.

\section{Results and Discussions}

\subsection{F Test}

Simultaneous trials or F-test is a test that held together in order to examine variables of the significant influence of promotion comprising advertising, sales promotions, public relations, personal selling, and direct marketing variables tourists visit.

Table 1

$\mathrm{F}$ Test result

\begin{tabular}{llrrrrrr} 
& \multicolumn{9}{c}{ ANOVA $^{\mathrm{b}}$} \\
Model & & Sum of & & Mean & & \\
& & Squares & df & Square & F & Sig. \\
\hline 1 & Regression & 1101,772 & 5 & 220,354 & 127,491 & &, $000^{\mathrm{a}}$ \\
& Residual & 162,468 & 94 & 1,728 & & \\
& Total & 1264,240 & 99 & & & \\
\end{tabular}

Predictors: (Constant), Direct Marketing, Public Relation, Advertising, Personal Selling, Selling Promotion.

Based on the results of data processing with the assistance of program SPSS 22.0 that has been displayed on the chart above, it can be seen as follows:

1. Hypothesis $\mathrm{HA}=$ Allegedly simultaneously X 1, X 2, X 3, X 4, X 5 have significant effect towards tourists visit. Ho = Allegedly simultaneously X 1, X 2, X 3, X 4, X 5 have not significant effect on tourist visitation.

2. Note: F count: 127.491

F table: 2,31

Manafe, J., Setyorini, T., \& Alang, Y. (2018). Influence of implementation on mix promotion model strategy towards tourist visitation in Indonesia. International Research Journal of Management, IT and Social Sciences, 5(6), 26-39. https://doi.org/10.21744/irjmis.v5n6.334 
3. Examination Criteria:

a) If $\mathrm{F}$ count $\leq \mathrm{F}$ table, Ho is accepted and $\mathrm{Ha}$ is rejected. in contrary,

b) If $\mathrm{F}$ count $\geq \mathrm{F}$ table, Ho is rejected and $\mathrm{Ha}$ is accepted.

4. Comparing F count and F table: the value of F count $>F$ table $(127.49>2.31)$.

Based on statistical test with F test method, in which the significant level gained is 0.007 of significant standard i.e. $5 \%$ or 0.05 df 1 (number of variables -1 or $5-1=4)$ and $\mathrm{df} 2(\mathrm{n}-\mathrm{k}-1)$ or $100-5-1=94$ ( $\mathrm{n}$ is the number of respondents, while $\mathrm{k}$ is the number of independent variables). The comparison between $\mathrm{F}$ count $\mathrm{F}$ table i.e. F count is 127.49 greater than F table $2.31(2.31>127.49)$, then it can be inferred that Ho is rejected and Ha is accepted. In other words, simultaneously, mix promotion has an impact on tourist visitation.

\subsection{T-Test}

The examination has been conducted to see how far the influence of partial $\mathrm{X}$ variable towards $\mathrm{Y}$ variables is. Based on the results using the SPSS program, it can be summarized as follows:

Table 2

T-Test Results

\begin{tabular}{lrrrrrr}
\hline Model & \multicolumn{2}{c}{$\begin{array}{c}\text { Unstandardized } \\
\text { Coefficients }\end{array}$} & \multicolumn{2}{c}{$\begin{array}{c}\text { Component } \\
\text { Coefficients }\end{array}$} & & \\
\cline { 2 - 5 } & \multicolumn{2}{c}{ B } & Std. Error & Beta & t & Sig. \\
\hline (Constant) & $-3,108$ &, 758 & & $-4,097$ &, 000 \\
ADVERTISING &, 434 &, 109 &, 264 & 3,969 &, 000 \\
Sales Promotion &, 478 &, 120 &, 327 & 3,989 &, 000 \\
Public Relation &, 085 &, 068 &, 080 & 1,248 &, 215 \\
Personal Selling &, 260 &, 064 &, 293 & 4,068 &, 000 \\
Direct Marketing &, 164 &, 127 &, 073 & 1,291 &, 200 \\
\hline
\end{tabular}

a) Hypothesis:

1) HA: allegedly partially $X 1, X 2, X 3, X 4, X 5$ have an effect towards tourists visit.

2) HO: allegedly partially $X 1, X 2, X 3, X 4, X 5$ have no effect towards the tourists visit.

b) Decision-making rule is by comparing $t$ count with $t$ table. If $t$ count $>t$ table, Ho is rejected and Ha is accepted, contrary, if $\mathrm{t}$ count $<\mathrm{t}$ table, Ho is accepted and Ha is rejected. It can also be compared alpha value (0050) or 5\%: $2=2.5 \%$ ( 2 sides test) in independent degrees $(\mathrm{df}) \mathrm{n}-\mathrm{k}-1$ or $100-5-1=94$ ( $\mathrm{n}$ is the number of respondents and $\mathrm{k}$ is the number of independent variables). Testing with 2 sides (significant 0.025$)$ with significant values ( $\mathrm{P}$ value Value): If $\mathrm{P}-$ Value $>0.05$ then the hypothesis is rejected. In contrary, if $\mathrm{P}-\mathrm{Value}<0.05$ then the hypothesis is accepted.

c) Note

T count $=(X$ 1), 3,969 (X 2) (X 3), 3,989 1,248, (X 4) 4,068, (X 5) 1,291

Table $\mathrm{t}=1.98525=1.985$

d) Comparing t count with t table:

1) Advertising (X 1): The value of $t$ count $>t$ table $(3,969<1,985)$

Based on the results of comparison between $t$ count and t table for variable advertising, it is found that $t$ count value is greater than $t$ table $(3,969>1.985)$. In addition, the significant value/ $P$-Value obtained is 0.00 , so when it is compared with the alpha value 0.05 , then the significant value is smaller than the alpha value $(0.00<0,05)$. This indicates that the $\mathrm{Ha}$ is accepted and $\mathrm{Ho}$ is rejected, or in other words, the advertising variable has a significant impact towards tourists visit. 
2) Sales Promotions (X 2): The value $t$ count $>t$ table $(3,989<1,985)$

Based on the results of comparison between $t$ count and t table for advertising variable, it has been found that the value of $t$ count is greater than $t$ table $(3,989>1.985)$. Besides that, significant $/ \mathrm{P}$-Value obtained is 0.00 , that is, compared by the alpha value of 0.05 , the value of significant /P-value is smaller than alpha $(0.00<0,05)$. This indicates that the $\mathrm{Ha}$ is accepted and Ho is rejected, or in other words, the variable of sales promotion has got effect significantly towards tourist visitation.

3) Public Relations (X 3): The value t calculate $<$ t table $(1.248<1,985)$

Based on the results of the comparison between $t$ count and table for advertising variable, it is found that $t$ count is smaller than $\mathrm{t}$ table $(1,248>1.985)$. In addition, significant value / $\mathrm{P}$-Value obtained is 0.21 . Compared with the alpha value of 0.05 , significant value $/ \mathrm{P}$-value is greater than alpha $(0.21>0.05)$. This indicates that $\mathrm{Ha}$ is rejected and Ho is accepted. In other words, the public relation has no impact significant impact on tourist visitation.

4) Personal Selling (X 4): T count value < t table (4.068 > 1.985)

Based on the results of the comparison between $t$ count and table for advertising variable, it is found that the value of $\mathrm{t}$ count is greater than $\mathrm{t}$ table $(4,068>1.985)$. In addition, significant value / P-Value obtained is 0.00 . Compared with the alpha value of 0.05 , the significant value / $\mathrm{P}$-value is smaller than alpha value $(0.00<0,05)$. This indicates that $\mathrm{Ha}$ is accepted and Ho is rejected. In other words, Personal Selling variable has a significant impact on tourists visit.

5) Direct Marketing (X 5): T count value < t table $(1.291<1,985)$

Based on the results of the comparison between $t$ count and table for advertising variable, it is found that the value of $t$ count is smaller than $t$ table $(1,291>1,985)$. In addition, significant value / $\mathrm{P}$-Value obtained is 0,20 . Compared with the alpha value of 0.05 , the significant value / P-value is greater than alpha value $(0.20>0,05)$. This indicates that $\mathrm{Ha}$ is rejected and Ho is accepted. In other words, direct marketing does not significantly impact tourist visitation.

On the hypothesis of examination results, there are two sub-promotion mix variables that insignificant i.e. public relations variable (X 3) and direct marketing variable (X 5).

\subsection{Multiple Linear Regression Analysis}

In analyzing how the implementation of promotional mix strategy influences the increase in tourists visitation to Rote Island, the researchers used statistical analysis with multiple linear regression calculation methods using SPSS tool 22. Following are the results of calculations using SPSS.

Table 3

Recap of the multiple regression (Coefficient) Coefficients

\begin{tabular}{|c|c|c|c|c|c|c|c|c|c|c|}
\hline Model & $\begin{array}{l}\text { Unstar } \\
\text { Coef } \\
\text { B }\end{array}$ & $\begin{array}{l}\text { ardized } \\
\text { ients } \\
\text { Std. } \\
\text { Error }\end{array}$ & $\begin{array}{l}\text { Component } \\
\text { Coefficients } \\
\text { Beta }\end{array}$ & $\mathrm{t}$ & Sig. & $\begin{array}{l}\text { Co } \\
\text { Zero- } \\
\text { order }\end{array}$ & $\begin{array}{c}\text { relatio } \\
\text { Parti } \\
\text { al }\end{array}$ & Part & $\begin{array}{l}\text { Colli } \\
\text { Stat } \\
\text { Toler } \\
\text { ance }\end{array}$ & $\begin{array}{l}\text { earity } \\
\text { tics } \\
\text { VIF }\end{array}$ \\
\hline (Constant) & $-3,108$ &, 758 & & $-4,097$ &, 000 & & & & & \\
\hline ADVERTISING & ,434 & , 109 & ,264 & 3,969 & ,000 &, 841 & ,379 & , 147 & ,309 & 3,234 \\
\hline Sales Promotion & 478 & 120 & ,327 & 3,989 &, 000 & ,868 & ,380 & 147 & ,204 & 4,907 \\
\hline Public Relation & ,085 & ,068 & , 080 & 1,248 & ,215 & ,740 & ,128 & ,046 & ,333 & 3,007 \\
\hline Personal Selling & 260 & ,064 & 293 & 4,068 & ,000 & ,863 & ,387 &, 150 & ,264 & 3,788 \\
\hline Direct Marketing & 164 & 127 & 073 & 1,291 & ,200 & ,737 & 132 & ,048 & ,425 & 2,355 \\
\hline
\end{tabular}

In the coefficients table, column B at constant (a) is -3.108 , whereas the value of advertising $(\mathrm{b} 1 \mathrm{x} 1)=0.434$, sales promotions $(\mathrm{b} 2 \times 2)=0.478$, public relations $(\mathrm{b} 3 \times 3)=0085$, personal selling $(\mathrm{b} 4 \times 4)=0.260$ and direct marketing $(\mathrm{b} 5 \times 5)$ is 0.164 ; therefore, multiple regression equation may be stated: Formula: $\mathrm{Y}=\mathrm{a}+\mathrm{b} 1 \mathrm{x} 1+\mathrm{b} 2 \times 2+\mathrm{x} 3+\mathrm{b} 3 \mathrm{~b} 4 \mathrm{~b} 5 \times 5$ $+\mathrm{x} 4+\mathrm{e} ; \mathrm{Y}=-3.108+0.434+0.478+0085+0.260+0.164$

Manafe, J., Setyorini, T., \& Alang, Y. (2018). Influence of implementation on mix promotion model strategy towards tourist visitation in Indonesia. International Research Journal of Management, IT and Social Sciences, 5(6), 26-39. 
a) Constants (a) $=-3,108$.

This means that, if the value of the mix promotion $(\mathrm{X})$ is equal to zero, then the level of tourists visit increase to Rote Island variable will remain, namely $-3,108$.

b) Advertising Variable (X 1) $=0434$

It is regression coefficient values advertising variable (X 1) towards increased tourist Visitation (Y), that means, if the performance of advertising (X 1) experience increment one unit, then tourists visit will experience an increase 0.434 or $43,4 \%$. The coefficient is positive, that is, can be meant performance advertising (X 1) and tourist visitation (Y) have a positive relationship. The increase of the advertising performance (X 1) will increase tourist visitation $(\mathrm{Y})$.

c) Sales promotions variable (X 2) $=0478$

It is regression coefficient value of sales promotions (X 2) towards increased tourist Visitation (Y) that means if the performance of the advertising (X 1) experience increment one unit, then tourist's visitation will experience an increase of 0.478 or $47,8 \%$. The coefficient is positive. It means, between the performance of sales promotions (X 2) and tourist's visitation (Y), there is a positive relationship. The increase of sales promotions performance (X 2) will create an increase in tourist visitation $(\mathrm{Y})$.

d) Public relations variables $(\mathrm{X}$ 3) $=0085$

Regression coefficient value of sales promotions (X 3) towards increased tourist visitation (Y), that means, if public relations (X 3) experience increment one unit, then tourists visitation will experience an increase of 0.085 or $8,5 \%$. The coefficient is positive. It means, public relations performance and between performance (X 3) and tourists visitation $(\mathrm{Y})$ have got a positive correlation. The increase of public relations performance (X 3) will increase tourist visitation $(\mathrm{Y})$.

e) Personal Selling variable (X 4) $=0.260$

The regression coefficient value is Personal Selling (X 4) to increased tourist visitation (Y), meaning that if public relations (X 3) experienced a rise in one unit, then a tourist visitation will experience an increase of $26 \%$ or 0.260. Value of coefficient is positive; it means, between the performance of Personal Selling (X 4) and visitation (Y), there is a positive correlation. The increase in Personal Selling performance (X 4) will increase tourist visitation (Y).

f) Direct marketing variable (X 5) $=0.164$

It is the regression coefficient value of direct marketing (X 5) towards increased tourist visitation (Y). This means, if public relations (X 3) experience a rise in one unit, then a tourist visitation will also experience an increase of 0.164 or $16.4 \%$. The coefficient is positive. It means, between the performance of direct marketing (X 5) and tourists visitation $(\mathrm{Y})$, there is a positive correlation. The increase of direct marketing performance (X 5) will increase tourist visitation $(\mathrm{Y})$.

Multiple regression results above indicate that the independent variable of advertising, sales promotion, personal selling, public relations, direct marketing has a positive effect on dependent variables i.e. tourists visit. Each increment that occurs on the independent variable will be followed by the increase of the dependent variable. Next, there will be seen the level of influence on promotion mix implementation towards increased tourist visitation in the following summary table.

Table 4

Summary Model

\begin{tabular}{|c|c|c|c|c|c|c|c|c|c|c|}
\hline \multirow[t]{2}{*}{ Model } & \multirow[b]{2}{*}{$\mathrm{R}$} & \multirow{2}{*}{$\begin{array}{c}\mathrm{R} \\
\text { Square }\end{array}$} & \multirow{2}{*}{$\begin{array}{c}\text { Adjusted } \\
\text { R } \\
\text { Square }\end{array}$} & \multirow{2}{*}{$\begin{array}{l}\text { Std. The } \\
\text { error of } \\
\text { the } \\
\text { Estimate }\end{array}$} & \multicolumn{5}{|c|}{ Change Statistics } & \multirow[b]{2}{*}{$\begin{array}{l}\text { Durbin } \\
\text { Watson }\end{array}$} \\
\hline & & & & & $\begin{array}{l}\text { R Square } \\
\text { Change }\end{array}$ & $\begin{array}{c}\mathrm{F} \\
\text { Change }\end{array}$ & df1 & df 2 & $\begin{array}{l}\text { Sig. F } \\
\text { Change }\end{array}$ & \\
\hline 1 & $934^{\mathrm{a}}$ & 871 & ,865 & 1,31468 &, 871 & 127,491 & 5 & 94 &, 000 & 1,902 \\
\hline
\end{tabular}


There is information about the level of influence of entire independent variables towards the dependent variable. The influences are symbolized by $\mathrm{R}$ (correlation). As seen in the table of model summary, the value in $\mathrm{R}$ column is 0.934 . It means, influence of advertising variable, sales promotion, personal selling, public relations, and direct marketing


linear regression model is formed, it can be seen through the value of determination coefficient $(\mathrm{R}$ square $)=0.871$. The value reveals information that $87 \%$ value of increased tourists visit level to Rote Island could be explained by data of advertising, sales promotions, public relations, personal selling, and direct marketing, while the rest $13 \%$ of information about level of tourists visit Rote Island has not been able to be explained by the independent variable.

Based on the result, it can be seen that simultaneously, mix promotion comprising advertising, sales promotion, public relations and publicity, personal selling and direct marketing, towards tourists visit, is 0.871 or $87 \%$, while the rest of $13 \%$ is affected by other factors that not mentioned in the study. Progress and development of tourist destinations in Rote Island, the role of information and the promotion of tourism, especially through tourism sites on the internet, are needed since they can introduce tourism attractions can not be done through orally only, but also need to be supported by information technology. The existence of a tourism tour agency, that is, to market any information related to tourism potential in Rote Island is absolutely necessary in order to increase tourists visitation to Rote Island. Tourism tour agency has become a bridge between tourists and tourism actors. The charm of natural beauty will mean nothing in the absence of information through brochures, books, and other media. Tourism tour agency should be able to design, package tour information in accordance with the interest and the demand of tourists. Thus, prospective tourists who were formerly not interested going to Rote will finally decide to visit Rote Island.

Partially, there is a correlation between Advertising variable (X 1), Sales Promotion (X 2), Public Relations and Publicity (X 3), Personal Selling (X 4) and Direct Marketing (X 5) towards tourists visit (Y). To find out which variables are partially have got real effect towards the level of tourists to visit on natural tourism in Rote Ndao, the researchers conducted an examination that done partially. The results of the examination revealed that all five independent variables examined, i.e. advertising, sales promotion, public relations and publicity, personal selling and direct marketing, have got a correlation. Three variables of them i.e., advertising, sales promotion, and personal selling have a significant influence towards the visit of tourists to Rote Island, while two other variables i.e., public relations and direct marketing have no significant effect to tourists visitation.

Public relations variable has no effect since government of Rote Ndao Regency has never built a non-personal communication that aimed at changing negative opinion from community around Rote, and involved in audience coverage, as well as builds a cooperation with mass media, namely: Both national and private TV, as well as magazines, build a relationship to Nature Conservation Agency Indonesia, Forest Protection and Nature Conservation, Forestry Department, Pellindo III in order to develop and to manage tourism object. In an environment of work units of local government, the Department of culture and tourism is less related to evaluate marketing programs. This is needed to create a good internal relations. Department of culture and tourism has not programmed English language training for the motorbike general transportation/ taxis and minibus drivers. This aims at building society participation for the sake of supporting the promotion of tourism. Not only that, the Department of culture and tourism has not conducted training of tour guides. Through the training, it is expected, the tour guide will be able to serve foreign tourists when the tourists come to enjoy the beauty of the Rote Island. Department of culture and tourism is less working with related stakeholders, for examples, Rote police department and health service, in order to the empower community around tourist attractions places. Material that is needed to be socialized more is about knowledge in managing cottage or homestay, including how to keep a health and hygiene sanitation, how to create security. Understanding virtual world or internet must also be informed to local people.

Direct marketing variable does not have a significant influence towards the visit of tourists on Rote Island since local governments itself, is less in organizing marketing approach that can be used in marketing communication, which allows marketers to have its own strategy in relation to tourist visitation. Related to direct marketing, Department of culture and tourism is still less in conducting an annual event like Surfing Competition on the Nembrala beach, etc. In fact, the more events are organized, the more natural tourism objects would be introduced, as well as the art and culture of the local community. Through events, tourist's visitation would be increased.

Results of examination on tourists visitation to Rote Island through mix promotion strategy shows that the most appropriate mix promotion model that can be applied in Rote Island is advertising, sales promotion, and personal selling techniques. Based on our researches, they will increase tourist's visitation.

Manafe, J., Setyorini, T., \& Alang, Y. (2018). Influence of implementation on mix promotion model strategy towards tourist visitation in Indonesia. International Research Journal of Management, IT and Social Sciences, 5(6), $26-39$. 


\section{Model of tourism marketing promotional mix in Rote Ndao Regency}

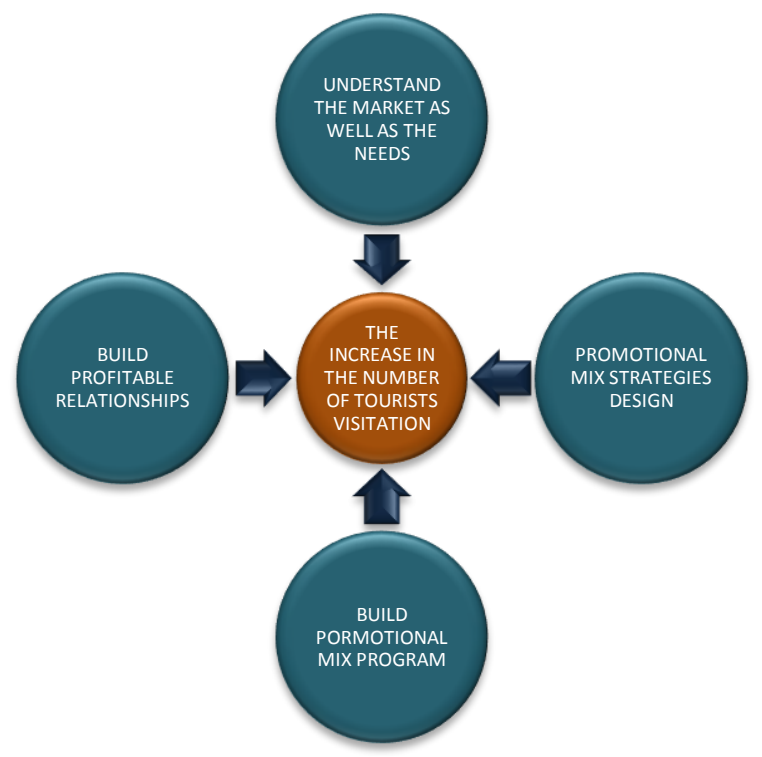

\section{Conclusion}

In this section, we present our conclusions. After that, we also offer some suggestions based on the result of our research. Based on the results of this verification research, it can be concluded as follows.

First, the examination results indicate that there is simultaneous and noticeable influence between the mix promotion that consists of advertising, sales promotion, public relations, personal selling, and direct marketing, towards tourists visit. The significant value is 0.871 or $87 \%$. The rest $13 \%$ is affected by other factors that not mentioned in the study. This shows that the model used in this research can be used to do further research. Second, multiple regression coefficients levels generated is $87 \%$. This indicates that the correlation between independent variables towards tourists visitation to Rote Island is very high. Third, partial test results indicate that independent variable consisting advertising, sales promotion and personal selling, has shown significant and positive influence towards the visit of tourists to Rote Island. This is indicated by a significant level of each variable is lower than $\alpha=$ $5 \%$. While variable of public relations and direct marketing does not have a significant influence towards the visit of tourists on the Island of Rote Ndao Regency. Fourth, based on statistical examination, it can also be concluded that the variable, that has got a dominant influence on tourists visitation, is sales promotion. It has a coefficient of partial determination. This sales promotion forms the most interesting tourist visitation, while variable that influences personal selling is less since communications conducted by employees or the tour guider are so limited due to their low English language skills and their less knowledge about tourist attractions. Fifth, results of the examination of tourists visitation to Rote Island through a strategy of promotion mix shows that the most appropriate model of promotion is by developing advertising, sales promotion, and personal selling techniques.

Next, Based on the findings researchers recommend some suggestions as follows: (1) government should maintain and improve motivation and ability of personal selling officer(s), for example, by improving English skills as well as giving extensive knowledge about tourism for the officer(s). This must be conducted so that the information provided can be clearly understood by foreigners/ international tourists. (2) The government should make improvements in infrastructure that supports tourism so that tourists will be more interested and be willing to re-visit Rote Island. (3) The government should conduct a research of mix promotion effectiveness so that the cost of the promotion will meet its target. (4) The government should do their best in creating positive destinations image. It is good that the Government tries to provide opportunities for the private sector to manage tourism professionally and keep doing monitoring and evaluation towards the private sector. (5) The government needs to provide understanding to all stakeholders, as well as to people, that the tourism sector is an important sector to be preserved. This will affect tourists 
decision to re-visit Rote Island. These things, of course, will improve the economy of the local area. The economy increase leads to the welfare of global society (Mardikanto, 2010).

Conflict of interest statement and funding sources

The authors declared that they have no competing interest. The study was financed by.

\section{Statement of authorship}

The authors have a responsibility for the conception and design of the study. The authors have approved the final article.

\section{Acknowledgments}

The authors would like to thank The Ministry of Research, Technology, and Higher Education- Ristekdikti for their financial support towards this research. They also would like to thank the Director of Kupang State Polytechnic for Her academic support towards this research.

Manafe, J., Setyorini, T., \& Alang, Y. (2018). Influence of implementation on mix promotion model strategy towards tourist visitation in Indonesia. International Research Journal of Management, IT and Social Sciences, 5(6), 26-39. https://doi.org/10.21744/irjmis.v5n6.334 


\section{References}

Buchari, A. (2004). Manajemen pemasaran dan pemasaran jasa. Alfabeta, Bandung.

Hadi, S. (1995). Metodologi Research Jilid IV. Yogyakarta: Andi Offset. 2004. Statistik Jilid, 3.

Hollloway. (1995). Manajemen Pemasaran Jasa, Teori dan Praktik. Jakarta: Salemba Empat.

Husein, U. (2005). Metode Penelitian. Jakarta: Salemba Empat

Kotler, P. (1964). Marketing mix decisions for new products. Journal of marketing research, 43-49.

Kotler, P., \& Wasana, J. (1994). Manajemen Pemasaran: Analisis, Perencanaan, Implementasi dan Pengendalian. Penerbit Erlangga.

Kotler, P., Keller, K. L., \& Bliemel, F. (2007). Marketing-management: Strategien für wertschaffendes Handeln. Pearson Deutschland GmbH.

Lumsdon, L. (1997). Tourism marketing. International Thomson Business Press.

Mardikanto, T. (2010). Komunikasi Pembangunan. Surakarta: Universitas Sebelas Maret \& PT. Telekomunikasi Indonesia Tbk.

Munarsi. (2005). Menapak Bumi, Menjelajah Alam Karangsambung Untuk Memahami Dinamika Bumi. Kebumen: UPT. BIKK LIPI Karangsambung.

Oliver, S. (2007). Strategi Public Relations. Jakarta: PT. Gelora Aksara Pratama.

Pattiasina, V., Sejati, F. R., Seralurin, Y. C., Batilmurik, R. W., \& Al Aziz, M. A. (2018). The impact of financial ratios towards profit changes. International Research Journal of Management, IT and Social Sciences, 5(5), 1-16.

Shim, T. A. (2003). Periklanan Promosi Aspek Tambahan Komunikasi Pemasaran Terpadu. Jakarta: Erlangga.

Sistaningrum, W. (2002). Manajemen penjualan produk. Yogyakarta: Kanisius.

Sugiyono, M. P. P. (2007). Pendekatan Kuantitatif. Kualitatif, dan R\&D, Bandung: Alfabeta.

Sutisna, S. E. (2002). ME. Perilaku Konsumen Dan Komunikasi Pemasaran.

Sutopo, H. B. (2002). Metodologi penelitian kualitatif.

Swastha, B. (2000). Irawan,(2005), Manajemen Pemasaran Modern. Liberty, Yogyakarta.

Swastha, B. D. H. 1984. Azas-azas marketing. Liberty. Yogyakarta.

Tjiptono, F., Chandra, G., \& Adriani, D. (2008). Pemasaran Strategik "Mengupas Topik Utama Pemasaran Strategik, Branding Strategy, Customer Satisfaction, Strategi Kompetitif, Hingga E-Marketing”. Yogyakarta: Andi offset Yogyakarta.

Yasid. (1999). Customer Behaviour. New York: Prentice Hall.

Yoeti Oka, A. (1996). Pengantar Ilmu Pariwisata, penerbit PT. Angkasa, Bandung. 


\section{Biography of Authors}

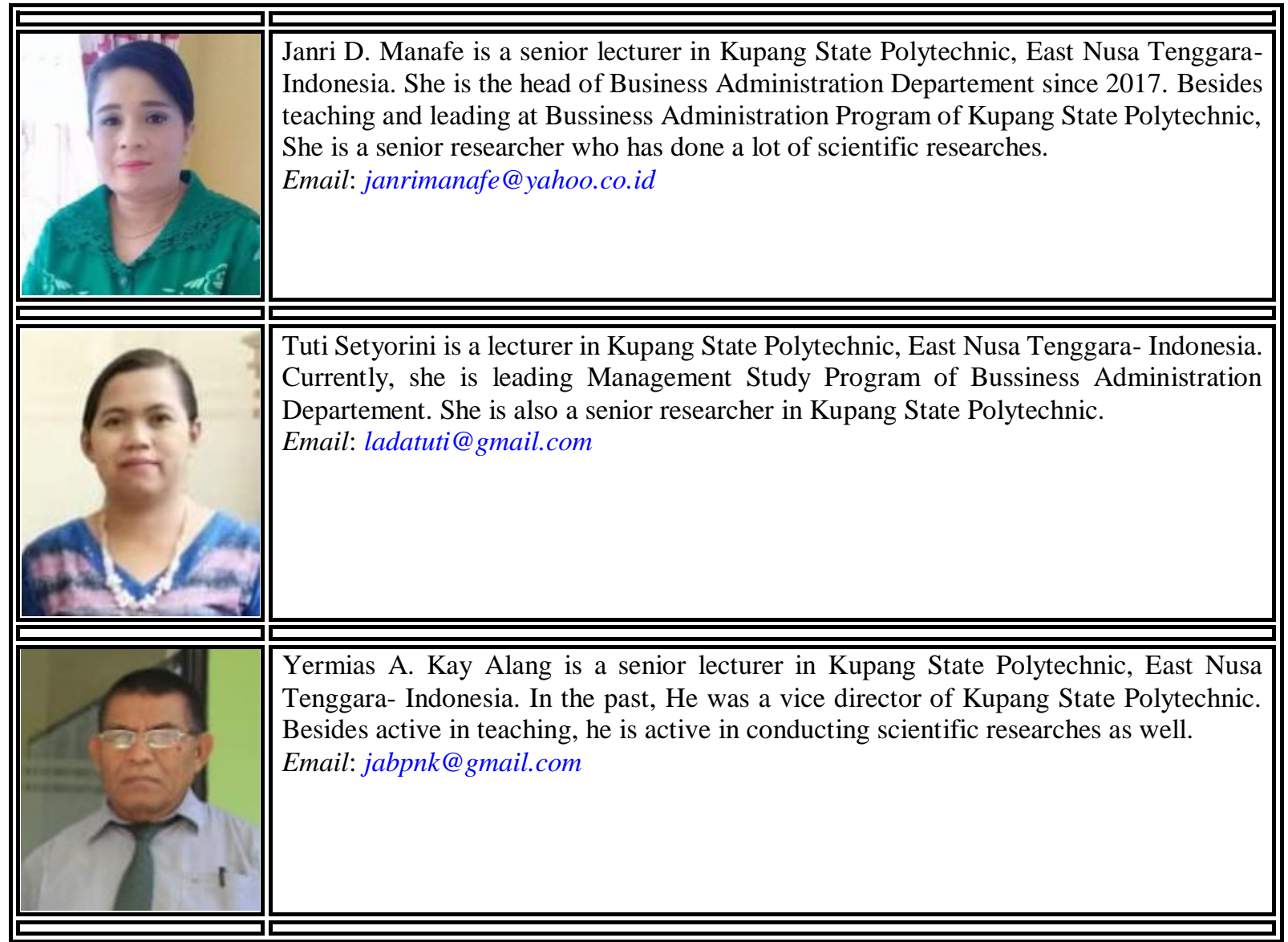

Manafe, J., Setyorini, T., \& Alang, Y. (2018). Influence of implementation on mix promotion model strategy towards tourist visitation in Indonesia. International Research Journal of Management, IT and Social Sciences, 5(6), $26-39$. https://doi.org/10.21744/irjmis.v5n6.334 